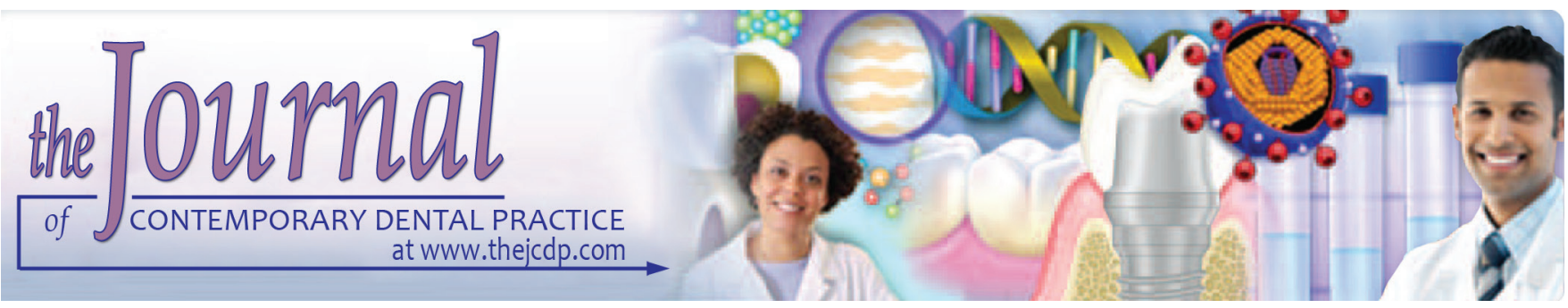

\title{
Prevalence of Periodontitis and Soft Tissue Lesions among Human Immunodeficiency Virus-positive Patients on Antiretroviral Therapy in Raichur Taluk, Karnataka, India
}

\footnotetext{
${ }^{1}$ Shrikanth Muralidharan, ${ }^{2}$ Arun Kumar Acharya, ${ }^{3}$ Shanthi Margabandhu, ${ }^{4}$ Sufiyan Kalekhan

${ }^{5}$ Sameer Ahsan, ${ }^{6}$ Dinraj Kulkarni
}

\begin{abstract}
Introduction: In countries where human immunodeficiency virus/acquired immunodeficiency syndrome (HIVIAIDS) is widespread and highly active antiretroviral therapy (HAART) medications are too expensive, or patients are failing HAART, oral disease management and risk remain an important issue.

Aim: The aim of the study was to evaluate the prevalence of oral mucosal lesions and periodontitis among the HIV-positive adult patients and assess the association of these lesions with age, sex, duration of HIV, time on ART, dietary habits, and oral hygiene habits.
\end{abstract}

Materials and methods: Sample size was 170. Demographic data of the patients along with community periodontal index (CPI) and loss of attachment (LA) were recorded. Oral soft tissue lesions, such as ulcerations, sores, erosions, and fissures were also recorded. The study was carried out in Raichur Taluk, Karnataka, India. Convenience sampling design was followed.

${ }^{1}$ Department of Public Health Dentistry, M. A. Rangoonwala College of Dental Sciences \& Research Centre, Pune, Maharashtra, India

${ }^{2}$ Department of Public Health Dentistry, Navodaya Dental College \& Hospital, Raichur, Karnataka, India

${ }^{3}$ Department of Public Health Dentistry, Mathrushri Ramabai Ambedkar Dental College and Hospital, Bengaluru, Karnataka India

${ }^{4}$ Department of Prosthodontics, KVG Dental College and Hospital, Sullia, Karnataka, India

${ }^{5}$ Private Practitioner, Pune, Maharashtra, India

${ }^{6}$ Department of Oral pathology, M. A. Rangoonwala College of Dental Sciences \& Research Centre, Pune, Maharashtra India

Corresponding Author: Shrikanth Muralidharan, Department of Public Health Dentistry, M. A. Rangoonwala College of Dental Sciences \& Research Centre, Pune, Maharashtra, India, Phone: +918308008831, e-mail: shrikanthmuralidharan23@gmail.com
Statistical Package for the Social Sciences (SPSS) version 20.0 (Chicago, USA) was used for data analysis. Chi-square test was carried out; $p<0.05$ was considered to be statistically significant.

Results: There was no association between the oral mucosal conditions and the age and the adverse habits, such as tobacco and alcohol, CD4 count, and the time duration of HIV and ART among these patients. A higher percentage of people with 4 to $5 \mathrm{~mm}$ of pockets was seen with those who cleaned their teeth with a finger, which was statistically significant.

Clinical significance: The present study highlights the poor condition of the oral health of these patients and their unmet dental needs.

Keywords: Adults, Antiretroviral therapy, Human immunodeficiency virus, India, Periodontitis.

How to cite this article: Muralidharan S, Acharya AK, Margabandhu S, Kalekhan S, Ahsan S, Kulkarni D. Prevalence of Periodontitis and Soft Tissue Lesions among Human Immunodeficiency Virus-positive Patients on Antiretroviral Therapy in Raichur Taluk, Karnataka, India. J Contemp Dent Pract 2018;19(1):42-46.

Source of support: Nil

Conflict of interest: None

\section{INTRODUCTION}

The growing number of people living with HIV/AIDS (PLWHA) represents a serious health and economic burden that the world is facing. ${ }^{1}$ The United Nations Programme on AIDS estimates that there are 33.4 millions who are suffering from HIV infection in the world. This is $20 \%$ more than what it was for the year 2001. In the year 2011 to 2012, 1.67 lakh cases of HIV were identified. ${ }^{2}$ By challenging HIV-positive individuals' own hostile attitudes toward the disease, at times, it may be 
possible to improve their overall health. ${ }^{3}$ People fear that they might be ostracized from the society if their infection status is revealed. ${ }^{4}$ The HIV prevention must be, therefore, a multidisciplinary approach involving physicians, dentists, pharmacists, nurses, health educators, therapists, and other healthcare providers. ${ }^{5}$ According to the National AIDS Control Organization, in India, there are six high prevalent states-Karnataka, Maharashtra, Andhra Pradesh, Tamil Nadu, and Kerala and 76\% of PLWHA belong to these states. ${ }^{6}$ People with low income have the most limited access to education, prevention, and treatment. ${ }^{7}$ In countries where HIV / AIDS is widespread and HAART medications are too expensive, or patients are failing HAART, oral disease management and risk remain an important issue. ${ }^{8}$ A variety of conditions affecting oral mucosal tissues may provide the physician with additional knowledge of individual patients' biological responses to their HIV infection. ${ }^{9}$ Oral lesions that are strongly associated with HIV infections include oral candidiasis, hairy leukoplakia, Kaposi sarcoma, linear gingival erythema, necrotizing ulcerative gingivitis, necrotizing ulcerative periodontitis, and non-Hodgkin lymphoma. ${ }^{1,4,10-13}$ Oral lesions are seen in HIV patients and can serve to determine the progress and the severity of the underlying disease. ${ }^{14,15}$ Oral diseases, such as dental caries, periodontal disease, tooth loss, oral mucosal, and oropharyngeal cancers, HIV / AIDS-related oral disease, and orodental trauma are major public health problems worldwide. ${ }^{16}$ There is a need for careful oral examination as oral manifestations can act as an indicator for immune suppression, especially in resources-deficient clinical settings, and also in probable diagnosis of new cases of HIV. ${ }^{12}$ The degree of immunological damage and the potential for recovery under therapy are not always predictable. ${ }^{17}$ The prevention, diagnosis, treatment, and control of the oral manifestations should be part of the objectives of every dental health professional. ${ }^{11}$ Dental services, therefore, have a definite role in the primary prevention of HIV by providing information about HIV and promoting oral health through early diagnosis and treatment of the oral manifestations of HIV / AIDS. ${ }^{5}$ The aim of our study was to determine the prevalence of oral soft tissue lesions among HIV-positive patients on ART for more than 1 year.

\section{MATERIALS AND METHODS}

The study design was cross-sectional in nature. Before the start of the study, ethical clearance was obtained from the Institutional Ethical Committee of Navodaya Dental College and Hospital, Raichur, Karnataka, India. Furthermore, permission was obtained from the medical superintendent of the District Civil Hospital, Raichur
(Raichur Institute of Medical Sciences). A pilot study was carried out on 30 patients and based on the findings of the pilot study, the final sample size was decided to be 170. Convenience sampling technique was used. The inclusion criterion was that the patients above 18 years of age be on ART for 1 year or more. A written consent was taken from all the participants. Oral examination was carried out by a calibrated examiner $(\kappa=0.91)$. The CPI and LA were recorded along with demographic details of the patients. The universal precautions of asepsis were duly maintained. The data were analyzed using SPSS version 16.0 package.

\section{RESULTS}

Among the $170 \mathrm{HIV}$-positive patients, 88 (51.8\%) were males and $82(48.2 \%)$ were females. A total of $153 \mathrm{HIV}-$ positive patients had a normal extraoral appearance (83 [54.2\%] were males and 70 [45.8\%] females); 5 (2.9\%) had ulceration, sores, and erosions, fissures (head, neck, and limbs) (2 [51.1\%] males and 3 [48.9\%] females); 7(4.1\%) had ulceration, sores, and erosions, fissures (nose, cheeks, and chin) (3 [51.8\%] males and 4 [48.2\%] females); 3 (1.8\%) women had ulceration, sores, erosions, and fissures along the vermilion border; 2 (1.2\%) women had other swellings of the face and the jaw. More males showed the presence of oral lesions than the females (Table 1). Higher percentage of pigmentation was seen among the females than males. Males also showed smoker's melanosis (Table 2). There was no statistically significant association of the oral mucosal conditions with age, adverse

Table 1: Distribution of the participants based on the presence or absence of oral mucosal lesions

\begin{tabular}{llll}
\hline $\begin{array}{l}\text { Oral mucosal } \\
\text { lesion }\end{array}$ & Males, $n(\%)$ & Females, $n(\%)$ & Total, $n(\%)$ \\
\hline Present & $41(46.6)$ & $34(41.5)$ & $75(44.1)$ \\
Absent & $47(53.4)$ & $48(58.5)$ & $95(55.9)$ \\
\hline Total & $88(100)$ & $82(100)$ & $170(100)$ \\
\hline$\chi^{2}=0.45, \mathrm{df}=1, \mathrm{p}=0.50$ & &
\end{tabular}

$\chi^{2}=0.45, \mathrm{df}=1, \mathrm{p}=0.50$

Table 2: Genderwise distribution of the HIV-positive patients based on the type of oral mucosal lesion present

\begin{tabular}{|c|c|c|c|}
\hline $\begin{array}{l}\text { Oral mucosal } \\
\text { condition }\end{array}$ & Males, $n(\%)$ & Females, $n(\%)$ & Total, $n(\%)$ \\
\hline Normal & $47(49.5)$ & $48(50.5)$ & $95(100)$ \\
\hline Leukoplakia & $3(100)$ & $0(0.0)$ & $3(100)$ \\
\hline Ulcer & $1(50.0)$ & $1(50.0)$ & $2(100)$ \\
\hline Candidiasis & $0(0.0)$ & $1(100)$ & $1(100)$ \\
\hline Pigmentation & $20(46.5)$ & $23(53.5)$ & $43(100)$ \\
\hline Smoker's melanosis & $11(100)$ & $0(0.0)$ & $11(100)$ \\
\hline Depapillated tongue & 1 (33.3) & $2(66.7)$ & $3(100)$ \\
\hline $\begin{array}{l}\text { More than one } \\
\text { condition }\end{array}$ & $5(41.7)$ & $7(58.3)$ & $12(100)$ \\
\hline Total & $88(51.8)$ & $82(49.2)$ & $170(100)$ \\
\hline
\end{tabular}


Table 3: Genderwise distribution of HIV-positive patients based on their CPI score

\begin{tabular}{llll}
\hline CPI & Males, $n(\%)$ & Females, $n(\%)$ & Total, $n(\%)$ \\
\hline Healthy & $6(50.0)$ & $6(50.0)$ & $12(100)$ \\
Bleeding & $17(47.2)$ & $19(52.8)$ & $36(100)$ \\
$\begin{array}{l}\text { Calculus } \\
\text { Shallow pockets }\end{array}$ & $21(47.7)$ & $23(52.3)$ & $44(100)$ \\
$\begin{array}{l}(4-5 \mathrm{~mm}) \\
\begin{array}{l}\text { Deep pockets } \\
(>6 \mathrm{~mm})\end{array}\end{array}$ & $6(85.9)$ & $33(47.1)$ & $70(100)$ \\
Excluded sextant & $1(100)$ & $1(14.3)$ & $7(100)$ \\
\hline Total & $88(51.8)$ & $82(49.2)$ & $170(100)$ \\
\hline
\end{tabular}

habits, such as tobacco and alcohol, CD4 count, time since the patient was HIV positive, and the duration of ART. More females showed bleeding and calculus, while more males had pockets of 4 to 5 and $6 \mathrm{~mm}$ or more (Table 3 ). Higher percentage of people with 4 to $5 \mathrm{~mm}$ of pockets was seen with those who cleaned their teeth with their finger, which was statistically significant $\left(\chi^{2}=15.86, \mathrm{df}=3\right.$, $\mathrm{p}=0.001$; Graph 1). Those using toothpowder showed more shallow pockets than others, and it was found to be significant (Table 4). There was no statistically significant association of the CPI with age, sex, or socioeconomic status, time since the patient was HIV positive, CD4 count, method of cleaning, time of cleaning, and the frequency of changing the toothbrush and also the time, type, and the frequency of sweet consumption and the sweet score.

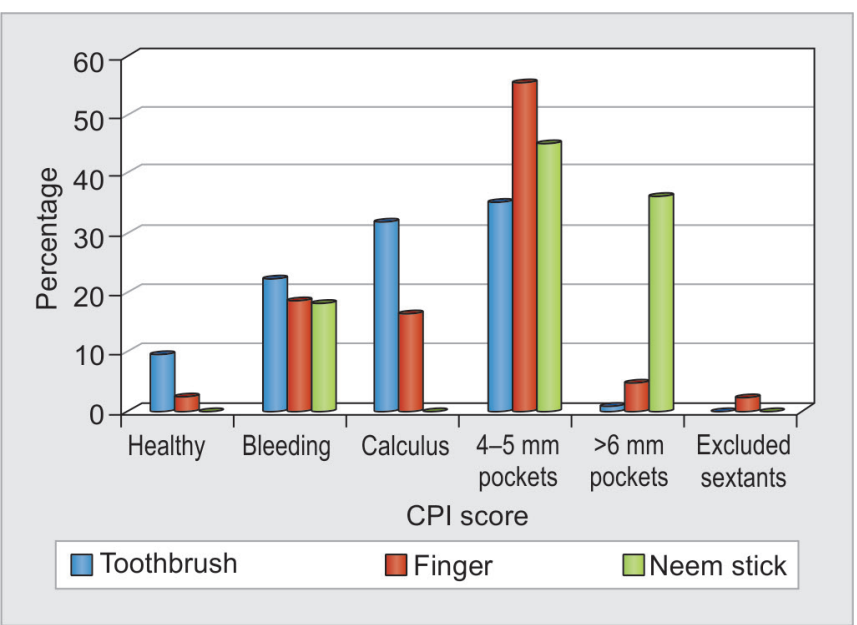

Graph 1: Distribution of the CPI score among the study participants based on the type of material used for cleaning the teeth

Males showed increased LA than females (Graph 2). As the age increased, there was an increase in the LA, and this was found to be statistically significant $\left(\chi^{2}=20.38\right.$, $\mathrm{df}=6, \mathrm{p}=0.002)$. No association between gender, $\mathrm{CD} 4$ count, time since HIV positive and on ART; material, frequency, and the time of cleaning the teeth, frequency of changing the toothbrush; and type and frequency of sweet consumption with LA was seen. Patients with increased sugar consumption in-between meals showed higher CPI scores $\left(\chi^{2}=7.344, \mathrm{df}=1, \mathrm{p}=0.007\right)$. Males had higher substance abuse than females (Table 5).

Table 4: Association between materials used to clean the teeth and CPI

\begin{tabular}{llllllll}
\hline $\begin{array}{l}\text { Material used to } \\
\text { clean the teeth }\end{array}$ & $\begin{array}{l}\text { Healthy } \\
n(\%)\end{array}$ & $\begin{array}{l}\text { Bleeding } \\
n(\%)\end{array}$ & $\begin{array}{l}\text { Calculus } \\
n(\%)\end{array}$ & $\begin{array}{l}4-5 \mathrm{~mm} \\
\text { pockets } n(\%)\end{array}$ & $\begin{array}{l}\geq 6 \mathrm{~mm} \\
\text { pockets } n(\%)\end{array}$ & $\begin{array}{l}\text { Excluded } \\
\text { sextants } n(\%)\end{array}$ & Total $n(\%)$ \\
\hline No material used & $0(0.0)$ & $3(25.0)$ & $0(0.0)$ & $5(41.7)$ & $4(33.3)$ & $0(0.0)$ & $12(100)$ \\
Toothpaste & $11(9.2)$ & $28(23.4)$ & $37(30.8)$ & $43(35.8)$ & $1(0.8)$ & $0(0.0)$ & $120(100)$ \\
Toothpowder & $0(0.0)$ & $0(0.0)$ & $0(0.0)$ & $4(66.6)$ & $1(16.7)$ & $1(16.7)$ & $6(100)$ \\
Charcoal & $1(3.1)$ & $5(15.6)$ & $7(21.9)$ & $18(56.3)$ & $1(3.1)$ & $0(0.0)$ & $32(100)$ \\
\hline Total & $12(7.1)$ & $36(21.2)$ & $44(25.9)$ & $70(41.2)$ & $7(4.1)$ & $1(0.5)$ & $170(100)$ \\
\hline
\end{tabular}

$\chi^{2}=10.25, d f=3, p=0.016$

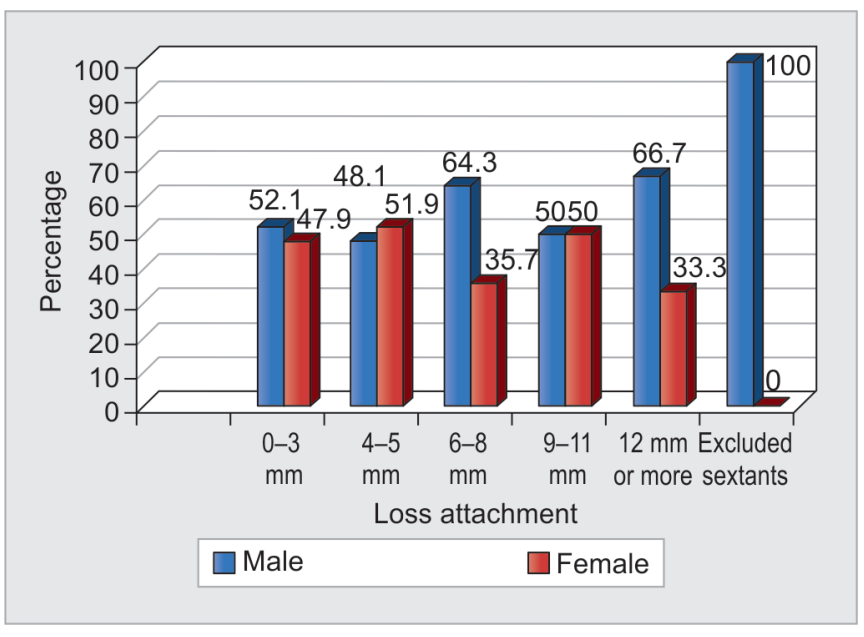

Graph 2: Genderwise distribution of the HIV-positive patients based on the LA
Table 5: Genderwise distribution of HIV-positive patients based on the type of adverse habits

\begin{tabular}{llll}
\hline Type of adverse habits & $\begin{array}{l}\text { Males, } \\
n(\%)\end{array}$ & $\begin{array}{l}\text { Females, } \\
n(\%)\end{array}$ & Total, $n(\%)$ \\
\hline No adverse habits & $53(40.8)$ & $77(59.2)$ & $130(100)$ \\
Cigarette & $1(100)$ & $0(0.0)$ & $1(100)$ \\
Bidi & $9(100)$ & $0(0.0)$ & $9(100)$ \\
Smokeless tobacco & $7(77.8)$ & $2(22.2)$ & $9(100)$ \\
Pan & $6(66.7)$ & $3(33.3)$ & $9(100)$ \\
Alcohol & $2(100)$ & $0(0.0)$ & $2(100)$ \\
Gutkha & $1(100)$ & $0(0.0)$ & $1(100)$ \\
Areca nut & $1(100)$ & $0(0.0)$ & $1(100)$ \\
More than one habit & $8(100)$ & $0(0.0)$ & $8(100)$ \\
\hline Total & $88(51.8)$ & $82(48.2)$ & $170(100)$ \\
\hline
\end{tabular}




\section{DISCUSSION}

The present study involved $170 \mathrm{HIV}$-positive patients who were on ART for more than 1 year from the entire Taluk of Raichur, Karnataka. This was lesser than the study carried out in South Africa (175) ${ }^{18}$ and Argentina (200). ${ }^{19}$ The mean age of the HIV-positive patients in Raichur was $37.17( \pm 8.21)$, similar to the studies in Thailand ${ }^{20}{ }^{\mathrm{Nepal}},{ }^{21}$ and Tanzania. ${ }^{22}$ In the present study, $44.2 \%$ had some or the other form of oral lesion lesser than the study findings in Thailand $(64.6 \%),{ }^{20}$ but higher than the study findings of Nepal $(40.0 \%) .{ }^{21}$ A total of $6.5 \%$ had smoker's melanosis higher than the study findings of Thailand $(2.02 \%) .{ }^{20}$ When an association was done between the adverse habits and the oral lesions, it was not found to be significant, which could be due to responder's bias. The study in Chennai, India, reported $0.5 \%$ oral submucous fibrosis and $1.1 \%$ of leukoplakia cases, due to the habit of chewing areca nut and tobacco and smoking tobacco. ${ }^{23}$ Only $0.6 \%$ had candidiasis in the present study, lesser than the study results of Thailand $(2.02 \%),{ }^{20} \mathrm{Nepal}$ $(16.0 \%),{ }^{21}$ and Mangaluru, India $(12.0 \%) .{ }^{24}$ We could not find any statistically significant correlation between the CD4 count and the oral infections unlike the study in Nepal. ${ }^{25}$ In another study in Nepal, oral candidiasis (21\%) and oral melanosis (21\%) were the most common lesions, followed by linear gingival erythema, oral hairy leukoplakia, necrotizing ulcerative periodontitis / gingivitis, herpes labialis, parotid gland enlargement, and recurrent aphthous ulcers. ${ }^{17}$ In contrast, we could not find such a high prevalence in our study, which may be due to the fact that the participants were already on drugs that helped to improve the immunity. It may be concluded that HAART seems to avoid progressive periodontal damage even in individuals with a longer period of HIV infection. ${ }^{17}$ A study in Tamil Nadu, India, also did not find any association between the oral manifestations and the CD4 count or ART treatment which was similar to the present study. ${ }^{26}$ Some authors have reported that a low CD4+ T-cell count does not appear to be a risk factor for increased severity of chronic periodontitis, which is also the observation we made through our findings. ${ }^{14,25}$ A study carried out in South India showed that even though there was a high prevalence of oral soft tissue lesions, such as ulcerative gingivitis and periodontitis, there was no significant association with low CD4 count, on the contrary, a study in South Africa, ${ }^{27}$ Nepal, ${ }^{17}$ Ujjain, and India ${ }^{28}$ showed worsening of the oral health with fall in the CD4 count. No angular cheilitis was seen in the Raichur patients, whereas a study in Mangaluru, India reported $12.8 \%$ of cases of angular cheilitis. ${ }^{24}$ A study in Iran showed higher prevalence of periodontal diseases (44\%), hyperpigmentation (42\%), and erythematous candidiasis (36\%) with a statistically significant association between the CD4 count and the oral lesions. ${ }^{29}$ In the present study, $21.2 \%$ had bleeding on probing lesser than the study findings of Thailand $(89.9 \%) .{ }^{20}$ Furthermore, $45.2 \%$ had periodontitis lesser than the study in Mangaluru, India, ${ }^{30}$ where $52.0 \%$ had periodontitis. In another study in Germany, Fricke et $\mathrm{al}^{17}$ evaluated 80 HIV-positive patients and observed that periodontitis was present in $73.2 \%$ participants. The study also documented that smoking is an enhancer for attachment loss of periodontal tissues and smoking has a strong influence on the progression of periodontal disease independent of the immunological status. Since the parameters of recording periodontitis were different, we could not make a direct comparison, but in contrast to the findings of their study, we could not establish any association between smoking and periodontitis. The periodontal health status was also poorer than our findings in the study in Argentina where 69.0\% had calculus, 25.0\% shallow pockets, and $6.0 \%$ deep pockets. ${ }^{19}$

The study had certain limitations like convenience sampling being followed since barriers related to the setup were a problem. People reported from far off rural areas; not all agreed to spare time. Furthermore, since no incentives to participate in the study were provided, reluctance and ignorance were a common response. We relied wholly on the information provided by the patients at the ART centers regarding their adverse habits. The data were collected in the presence of the personnel at the ART center. There is always a possibility of reporting bias/social desirability bias creeping in the study. Although health education was provided and sensitization was done, follow-up of these patients to check the efficiency of one-to-one counseling could not be done due to time and workforce constraints. The study also involved only those who reported to the center for drugs. Data could not be obtained for those patients who were defaulters and did not report to the center for further regime, since factors interfering with their adherence to ART drugs and also the multiplication of the HIV-1 virus in the system could lead to further health deterioration.

\section{CONCLUSION}

The present study among the 170 HIV-positive adult patients on ART for more than 1 year in Raichur Taluk, Karnataka, India, highlights the poor condition of the oral health of these patients and their unmet dental needs. Almost half of the population had some or the other form of oral lesion. This could be attributed to the underlying HIV as well as alcohol and tobacco addictions, along with the lack of proper oral hygiene methods. Still participants used materials apart from toothpaste and brushes that shows the poor plight of awareness regarding need for 
a good oral health among the participants. Less than a quarter of the study population was free of periodontitis. There is a definite need for comprehensive intervention to reduce the disease burden among these people.

The study thus highlights the need for the following:

- Oral health promotion and intervention

- Subsidized treatment plans

- Mobilization of the medical and allied health professionals for spreading the word of importance of oral health, especially among the HIV-positive patients.

- Further trials for efficacy of preventive therapies, such as fluorides and sealants in relation to the HIV-positive patients.

- Have a public health dentist at all the ART drug distribution centers for serving the registered people.

- Steps to remove the misconceptions and ignorance related to HIV / AIDS directed against the people who suffer from the disease.

\section{REFERENCES}

1. Khan SA, Moorthy J, Omar H, Hasan SS. People living with HIV / AIDS (PLWHA) and HIV / AIDS associated oral lesions; a study in Malaysia. BMC Public Health 2012 Oct;12:850.

2. Sidibé M. UNAIDS Executive Director, Under Secretary, General of the United Nations, UNAIDS, Report on the Global AIDS Epidemic; 2012.

3. Steward WT, Chandy S, Singh G, Panicker ST, Osmand TA, Heylen E, Ekstrand ML. Depression is not an inevitable outcome of disclosure avoidance: HIV stigma and mental health in a cohort of HIV-infected individuals from Southern India. Psychol Health Med 2011 Jan;16(1):74-85.

4. Anish TS, Vijaykumar K, Simi SM. Determinants of rapid progression to immunodeficiency syndrome among people infected with human immunodeficiency virus, Kerala, India. Indian J Sex Transm Dis 2011 Jan;32(1):23-29.

5. Azodo CC, Ehizele AO, Umoh A, Ogbebor G. Preventing HIV transmission in Nigeria: role of the dentists. Malays J Med Sci 2010 Apr-Jun;17(2):10-17.

6. Ministry of Health and Family Welfare. NACO, Department of AIDS Control, Annual Report. 2011-2012.

7. Coelho KR. Challenges of the oral cancer burden in India. J Cancer Epidemiol 2012 Oct;2012:701932.

8. Chattopadhyay A, Patton LL. Smoking as a risk factor for oral candidiasis in HIV-infected adults. J Oral Pathol Med 2013 Apr;42(4):302-308.

9. Chapple IL, Hamburger J. The significance of oral health in HIV disease. Sex Transm Infect 2000 Aug;76(4):236-243.

10. Johnson NW. The mouth in HIV/AIDS: markers of disease status and management challenges for the dental profession. Aust Dent J 2010 Jun;55(Suppl 1):85-102.

11. Leao JC, Ribeiro CM, Carvalho AA, Frezzini C, Porter S. Oral complications of HIV disease. Clinics (Sao Paulo) 2009 May;64(5):459-470.

12. Gaurav S, Keerthilatha PM, Archna N. Prevalence of oral manifestations and their association with $\mathrm{cd} 4 / \mathrm{cd} 8$ ratio and HIV viral load in South India. Int J Dent 2011 Oct;2011:964278.

13. Sen S, Mandal S, Bhattacharya S, Halder S, Bhaumik P. Oral manifestations in human immunodeficiency virus infected patients. Indian J Dermatol 2010 Jan-Mar;55(1)116-118.
14. Khammissa R, Feller L, Altini M, Fatti P, Lemmer J. A comparison of chronic periodontitis in HIV-seropositive subjects and the general population in the Ga-Rankuwa Area, South Africa. AIDS Res Treat 2012 Jul;2012:620962.

15. Campo J, Cano J, del Romero J, Hernando V, del Amo J, Moreno S. Role of the dental surgeon in the early detection of adults with underlying HIV infection/AIDS. Med Oral Patol Oral Cir Bucal 2012 May;17(3):e401-e408.

16. Petersen PE, Bourgeois D, Ogawa H, Estupinan-Day S, Ndiaye C. The global burden of oral diseases and risks to oral health. Bull World Health Organ 2005 Sep;83(9):661-669.

17. Fricke U, Geurtsen W, Staufenbiel I, Rahman A. Periodontal status of HIV-infected patients undergoing antiretroviral therapy compared to HIV-therapy naive patients: a case control study. Eur J Med Res 2012 Jan;17(1):2.

18. Bajomo AS, Yusuf OA, Rudolph MJ, Tsotsi NM. Impact of oral lesions among South African adults with HIV/AIDS on oral health-related quality of life. J Dent Sci 2013 Dec;8(4):412-417.

19. Sánchez GA, D'Eramo LR, Lecumberri R, Squassi AF. Impact of oral health care needs on health-related quality of life in adult HIV patients. Acta Odontol Latinoam 2011;24(1):92-97.

20. Nittayananta W, Talungchit S, Jaruratanasirikul S, Silpapojakul K, Chayakul P, Nilmanat A, Pruphetkaew N. Effects of long-term use of HAART on oral health status of HIVinfected subjects. J Oral Pathol Med 2010 May;39(5):397-406.

21. Gaunt F, Rai A, Kinkel HT. Assessment of the oral health status of healthcare-seeking adults living with HIV in Kathmandu Valley, Nepal. Oral Health Dent Manag 2014 Jun;13(2):519-524.

22. Kahabuka FK, Petersen PE, Mbawala HS, Jürgensen N. General and oral health related behaviors among HIV positive and the background adult Tanzanian population. Oral Hyg Health 2014 Sep;2(5):1-6.

23. Rao UKM, Ranganathan K, Kumarasamy N. Gender differences in oral lesions among persons with HIV disease in Southern India. J Oral Maxillofac Pathol 2012 Sep-Dec;16(3):388-394.

24. Fox JE, Tobias CR, Bachman SS, Reznik DA, Rajabiun S, Verdecias N. Increasing access to oral health care for people living with HIV / AIDS in the U.S.: Baseline evaluation results of the innovations in oral health care initiative. Public Health Rep 2012 May;127(Suppl 2):5-16.

25. Naidu GS, Thakur R, Singh AK, Rajbhandary S, Mishra RK, Sagtani A. Oral lesions and immune status of HIV infected adults from eastern Nepal. J Clin Exp Dent 2013 Feb;5(1):e1-e7.

26. Vernon LT, Demko CA, Whalen CC, Lederman MM, Toossi Z, Wu M, Han Y, Weinberg A. Characterizing traditionally defined periodontal disease in HIV adults. Community Dent Oral Epidemiol 2009 Oct;37(5):427-437.

27. Tamí-Maury I, Coulibaly YI, Cissoko SS, Dao S, Kristensen S. First report of HIV-related oral manifestations in Mali. Pan Afr Med J 2012 Jan;11:18.

28. Kumar S, Mishra P, Warhekar S, Airen B, Jain D, Godha S. Oral health status and oromucosal lesions in patients living with HIV / AIDS in India: a comparative study. AIDS Res Treat 2014 Aug;2014:480247.

29. Davoodi P, Hamian M, Nourbaksh R, Ahmadi Motamayel F. Oral manifestations related to cd4 lymphocyte count in HIVpositive patients. J Dent Res Dent Clin Dent Prospects 2010 Autumn;4(4):115-119.

30. Hegde MN, Hegde ND, Malhotra A. Prevalence of oral lesions in HIV infected adult population of Mangalore, Karnataka, India. Bio Discov 2012 Mar;3(4):1-5. 